\title{
Between Appropriation and Occupation: \\ The Spatial Politics of 'Squatting' in East Berlin
}

\begin{abstract}
At the heart of this paper is a detailed reconstruction of the relatively unknown history of illegal occupation in East Berlin otherwise known as Schwarzwohnen. Schwarzwohnen was not a marginal phenomenon but involved thousands of citizens in the 1970s and 1980s in East Berlin and other major cities including Halle, Dresden, Leipzig, Potsdam, Erfurt and Jena. The paper follows the everyday practices adopted by so-called squatters in East Berlin. It places particular emphasis on the relationship between Schwarzwohnen and the articulation of alternative forms of dwelling and occupation that challenged official state priorities. To do so, it argues that the rise of Schwarzwohnen was part of a growing body of informal practices used by citizens in the GDR in response to housing insecurity and scarcity. These were efforts that highlighted the various ways in which citizens took control of their own housing needs outside the official housing system. They also anticipated the development of the oppositional cultures and infrastructures that erupted in the Eastern half of the city in the winter of 1989. At stake here, is an approach to housing insecurity that challenges our understanding of the socialist city and its (largely) peripheral place within urban theory.
\end{abstract}

\section{Keywords: Squatting; Socialist City; East Berlin; Housing Question; Urban Theory}




\section{Introduction}

This paper begins at the scene of an unusual protest. On June 12, 1981, a young woman sat down with her 11-month-old baby in front of the central department store on Alexanderplatz in what was then East Berlin. A cardboard placard was draped over the baby with a handwritten message in pen: "Who can help us, a young 21-year-old mum and an elevenmonth-old child, who have been forced to live in a backyard hole and who have received no support to improve our conditions?” Within a few minutes, a crowd had gathered to discuss the woman's (hereafter Frau S) situation. They were quickly dispersed by the police who escorted Frau S to the local station. Frau $\mathrm{S}$ was released without charge though her case was followed-up by officers at the Ministerium für Staatsicherheit (colloquially known as the Stasi, hereafter MfS) who concluded that she was "unstable, manic, spontaneous, impulsive, hysterical and overly emotional.”1

In the same report, it was noted that Frau S had first squatted an empty apartment on Anklamer Straße in November 1980 in order to escape a physically abusive relationship. After contacting local housing authorities, Frau S was instructed to leave the apartment. It was suggested that she move back in with her partner which she unsurprisingly rejected. In February 1981, she attended a public consultation with local authorities where she made a public petition to resolve her housing needs. It was finally agreed that Frau S would vacate the apartment in exchange for alternative housing. An apartment was secured in March 1981 though Frau S was unable to move in as it was already occupied and the tenant was refusing

\footnotetext{
${ }^{1}$ Der Bundesbeauftragte für die Unterlagen des Staatssicherheitsdienstes der ehemaligen Deutschen Demokratischen Republik (The Federal Commisioner for the Records of the State Security Service of the former German Democratic Republic, hereafter BStU). MfS, AOP, 14401/83, fols 183-186. All translations are the authors unless otherwise stated. All names have been changed.
} 
to leave. A couple of months later, another apartment was identified on Brunnenstraße. Frau S rejected the offer as the apartment had no cooking facilities and an outdoor toilet. She was threatened with a forced eviction whereupon she agreed to move on June $12 .^{2}$

On the date of the move, Frau S visited the local branch of the Communal Housing Authority (Kommunale Wohnungsverwaltung or KWV) and requested the issue of a reference certificate for a gas stove. The KWV refused to issue a certificate. A “violent exchange of words” ensued. Frau S explained that she could not cook for her child. A KWV official responded that this was Frau S's problem and not a matter for the KWV. It was at this point that Frau S - rather than moving into the apartment on Brunnenstraße - began her spontaneous protest on Alexanderplatz. ${ }^{3}$

While an exceptional act of public defiance, the actions undertaken by Frau S were, in many respects, symptomatic of wider frustrations with housing in the German Democratic Republic (GDR). As the historian Mary Fulbrook has argued, "housing was, and remained, a central problem of the SED (Sozialistische Einheitspartei Deutschlands or Socialist Unity Party of Germany) regime, and one of the chief causes of popular dissatisfaction”. "By far largest category of complains in individual citizens’ petitions or Eingaben,” Fulbrook continues, “were complaints about inadequate housing” (2005, p. 51; see Buck and Reuter, 1991). And yet, struggles in the area of housing have received relatively little scholarly attention even as the relationship between state and society has become an "ever-present theme" in research on the GDR (Coché, 2018, p. 219; see Betts, 2010; Jessen, 1995; Lindenberger, 1999; Palmowski, 2009; Port, 2007). Much of this work has attempted to clarify the degree to

\footnotetext{
2 Ibid.

${ }^{3}$ Ibid.
} 
which ordinary citizens were able to exercise their own agency while navigating the rules and strictures of a dictatorial regime characterised by intensive surveillance and repression. Housing, as the present paper shows, was an important part of this story. It was, after all, the East German state which assumed principle responsibility for the construction, maintenance and allocation of housing. The state was unable, however, to provide satisfactory housing for all its citizens. In large cities, many people were unable to obtain housing and - like Frau S took matters into their own hands. Against a backdrop of persistent housing scarcity, they chose to bypass the official allocation process and occupy properties illegally. What Udo Grashoff has recently described as "Schwarzwohnen” (“illegal living”), or “wohnen in Abriss" ("living in ruins”) as some residents preferred to call it, can be traced back to the occupation of a small apartment in 1967 on Kleine Marktstraße in the East German city of Halle (Grashoff, 2011a). Schwarzwohnen was not a marginal phenomenon but involved thousands of citizens in the 1970s and 1980s in Berlin and other major cities including Halle, Dresden, Leipzig, Potsdam, Erfurt and Jena. Smaller towns also bore witness to the phenomenon (AUTHOR; see Grashoff, 2011a; 2011b; Mitchell, 2015).

This paper seeks to reconstruct the history of Schwarzwohnen in the GDR. It shifts attention away from the mass-produced housing estates whose construction occupied an important place within a national narrative of architecture, design and urbanity (see Rubin, 2016; Zarecor, 2018). The paper traces instead the everyday practices adopted by so-called squatters in East Berlin placing particular emphasis on the relationship between Schwarzwohnen and the articulation of alternative forms of appropriation, dwelling and occupation that challenged official state priorities. While it would be tempting to read these practices through the actions of their Western counterparts and the large body of scholarship that has emerged in recent years on the history of squatting in Europe (Owens, 2009; Kadir, 
2016; SqEK, 2014; AUTHOR; AUTHOR), to do so risks undermining the distinctiveness of Schwarzwohnen and what it might tell us about the nature of housing insecurity in socialist cities located in Central and Eastern Europe (See Grashoff, forthcoming). The analysis offered here thus parts company with existing scholarship on squatting in some significant ways. It responds, in particular, to recent calls for the critical development of a more nuanced approach to socialist and post-socialist urbanisms (see Ferenčuhová, 2016; Gentile, forthcoming; Hirt, 2013;; Rubin, 2016; Tuvikene, 2016; Zarecor, 2018). This is an approach that combines and moves in three interconnecting stages. First, as an optic that seeks to historise accounts of housing insecurity through a granular examination of the tactics adopted by ordinary citizens in the GDR facing unacceptable living conditions. Second, as a conceptual framework that recognises the importance of the socialist and post-socialist city in extending our geographies of urban theory and in generating new ways of thinking about housing scarcity. Finally, as a diagnostic approach (Safransky, 2018) to the study of contemporary housing struggles in Berlin and their relationship to an older archive of dissent, resistance and self-determination. This paper does not, ultimately, seek to add impressionistic colour to our understanding of the everyday histories of the GDR. Rather, it draws attention to the relationship between the 'socialist city' and the conspicuously makeshift urbanisms it produced.

The paper builds on extensive archival research conducted in Germany over the past five years. Urban scholarship has increasingly recognised the role that different archives have come to play in how we research, think and inhabit cities (see AUTHOR) and the following investigation seeks to highlight their importance in understanding the socialist city and the nature of post-socialist urban change. While the archival footprint of Schwarzwohner living in East Berlin remains relatively modest, research conducted in institutional archives 
(Bundesarchiv, Landesarchiv, BstU) as well as other alternative spaces (Robert-HavemannGesellschaft and Papier Tiger Archiv) has yielded some important insights. Taken together, they offer a glimpse of a "hidden and unknown existing world" from which an alternative understanding of the city was assembled (Farge and Foucault 2016, p. 268). The main aim here, following Ann Laura Stoler, is to heed what she describes as the "ethnographic space of the archive". This is a space that resides, according to Stoler, in the "disjuncture between prescription and practice, between state mandates and the manoeuvres people made in response to them, between normative rules and how people actually lived their lives” (2009, p. 32; emphasis added).

The paper is divided into four parts. The first section re-traces the history of housing in the GDR and the many problems that ordinary citizens faced in meeting their basic needs. The second section offers a detailed analysis of the rise of Schwarzwohnen in East Berlin as part of a growing body of informal practices used by citizens in the GDR in response to housing insecurity and scarcity. These were practices as the third section of the paper shows that highlighted the various ways in which citizens took control of their own housing needs outside the official housing system. The fourth section of the paper examines the relationship of these activities to the oppositional cultures and infrastructures - including a new wave of squatting - that erupted in the Eastern half of the city in 1989 after the fall of the Berlin Wall. The paper concludes with some brief reflections on the historical significance of Schwarzwohnen to more recent struggles over housing in Berlin as well as wider debates within urban geography on the nature of the socialist city and the making of alternative urbanisms. 


\section{The Housing Question in the German Democratic Republic}

Throughout the course of its forty-year history, it was the 'housing question' that came to define the SED regime’s inability to meet the basic needs and aspirations of its citizens. "What was distinctive about the GDR," as Mary Fulbrook reminds us, "was the sheer extent to which the state took responsibility for housing” (2005, p. 50). The right to housing was, after all, enshrined in the East German constitution. According to Article 8, the "right to take up residence at any place was guaranteed” while Article 26 stated that "every citizen and every family shall be assured of a healthy dwelling befitting their needs.” This was further reflected in Section 94 of the 1976 Code of Civil Law (Zivilgesetzbuch der DDR) which noted that it was the primary responsibility of the socialist state to guarantee "all citizens and their families the right to housing” (Buck, 2004, p. 7). It is perhaps not surprising, therefore, that, if, in the West, one could blame the predations of market, in the GDR, it was the state that took the blame for poor unhealthy living conditions and widespread housing scarcity.

For officials in the GDR, it was the parlous state of housing in the wake of the Second World War that posed the most immediate challenge. Wartime destruction coupled with an influx of refugees from the East led to overcrowding and a general shortage of housing (Port, 2007, p. 33). In large cities including East Berlin, upwards of two thirds of the housing stock had been destroyed. Despite repairs, much of the older housing was, in many cases, barely fit for habitation and only continued to deteriorate with time (Fulbrook, 2005, p. 51). By the 1950s, central heating was still available in less than 3 per cent of residences. Only 30 per cent of residences had a toilet and 22 per cent a bath. Over 45 per cent of housing had been constructed before 1900 (Betts, 2010, p. 120). 
Housing policy in the GDR was largely characterised by a "high degree of continuity with the past”. The new socialist regime inherited a controlled economy in housing from the National Socialists and the Allied Control Council though what was intended as a temporary solution became, for the SED, a "guarantee of socialist housing” (Führer, 1995, p. 341-242). In practical terms, housing administration in the GDR was predominantly handled by the Communal Housing Association (Kommunale Wohnungsverwaltung or KWV) which was responsible, in the case of East Berlin, for managing over 72 per cent of East Berlin's properties. A further 14 per cent belonged to housing cooperatives and the remaining 14 per cent were owned privately and under the control of state-allocated trustees. ${ }^{4}$ Rents throughout the GDR were capped at 1930s levels and citizens were legally required to obtain permission from local housing authorities before they could take up residence at a given address and receive an official tenancy agreement (Grashoff, 2011b, p. 14-15). The KWV employed over 10,000 staff in East Berlin. Each district had their own sub-department which reported to a central office. While the KWV was lauded as one of the "most important organisations" in the city, staff were, in reality, overworked and underqualified and were on the sharp end of citizen complaints who criticised the "bureaucratic mind-set" and "heartlessness" of KWV employees. ${ }^{5}$ As one historian has shown, turnover in KWV was as high as $35 \%$ in some districts of East Berlin (Mitchell, 2015, p. 252).

Seen in this context, the organisation and management of housing in the GDR, in many ways, reflects wider scholarship on the limitations of the SED-regime as a so-called durchherrschte

\footnotetext{
${ }^{4}$ Landesarchiv Berlin (hereafter LAB), C Rep. 100-05, Nr. 1894/2. "Leistungsentwicklung der VEB KWV für die Wohnrauminstandhaltung und Maßnahmen zur weiteren Verbesserung der Führungstuatigkeit des Magistrats und der Räte der Stadtbezirke", August 11, 1980, Attachment 1.

${ }^{5}$ SAPMO, DY 30/22386, Abteilung Staats - und Rechtsfragen, "Einschätzung des Standes der Verwirklichung des Beschlusses der Stadtverordnetenversammlung zur Entwicklung der VEB, KWV", October 25, 1979; LAB, C Rep. 100-05, Nr. 1458, Magistrat von Berlin, Büro des Magistrats, “Eingabenbearbeitung, 2. Halbjahr 1970”, March 9, 1970, pp. 8-9.
} 
Gesellschaft (thoroughly-ruled society) (see Kocka, 1994). Efforts to address housing shortages were uneven and lacked coordination focusing, for the most part, on the construction of new homes. From 1958 onwards, this was overseen by the new established Ministry for Building and Construction though it was only in the early 1970s when Erich Honecker came to power that an ambitious building programme was initiated in order to transform the "living relationships" between architects and citizens. "Housing in our country,” as Honecker later proclaimed at the $8^{\text {th }}$ Building Conference of the SED in 1985, “is a public matter in which everyone actively participates.” Citizens were therefore encouraged to take part in a grassroots National Front (Nationale Front der DDR) campaign “Schöner unsere Städte und Gemeinde - Mach mit!” (“Better our cities and towns - Join In!”) in which they were expected to contribute to the "care and preservation of their residential areas”. ${ }^{6}$ The campaign called on citizens to "help with the improvement of housing conditions and social facilities” (quoted in Kreis, 2018: 55). While the DIY achievements of citizens were often reported in the local press, little sustained effort was made by the state's central organs to protect and restore the country's existing housing stock despite the fact that there were, by the late 1960s, upwards of 90,000 citizens searching unsuccessfully for housing in East Berlin (Rubin, 2016: 27).

An acute shortage of housing thus persisted especially in inner city neighbourhoods as ideological priority was given to large industrially manufactured estates on the outskirts of cities. The pace of construction accelerated in the 1970s though the state was unable to match its own wildly optimistic targets. There were over 600,000 people on official housing waiting

\footnotetext{
${ }^{6}$ Robert-Havemann-Gesellschaft Archiv (hereafter RHG), PS 72/14, Nachlass B. Holftreter, "Erich Honecker, Schlosswort auf der 8. Baukonferenz der ZK der SED," n.d. and "Aus dem Beschluss des Politbüros des ZK der SED und des Ministerrates der DDR über 'Grundsätze für die soziale Entwicklung von Städtebau und Architektur in der DDR'”, May 1982.
} 
lists in the early 1970s with waiting times averaging between six to eight years (Häusermann and Siebel, 1996, p. 169; Mitchell, 2015, 101). The cost of demolition and construction could not, in turn, be met by the state and as a result, thousands of properties fell into ruin and remained empty. The number of housing units actually built or modernised between 19761990 was only 1.7 million, way below the 2.8 million reported in official statistics (Buck and Reuter, 1991, p. 15). As a secret report commissioned by the SED in 1985 noted, there were over 235,000 empty properties across the GDR with particular concentrations in major cities such as Berlin, Dresden and Leipzig. As late as 1990, the number had risen to 400,000 while over 89,000 families and 382,000 individuals were still without accommodation of their own (Buck, 2004, p. 344, 383; see also Häusermann and Siebel, 1996). While homelessness may not have officially existed in the GDR, many citizens were forced into a range of temporary and increasingly informal arrangements (couch surfing, living with relatives, subletting, illegal squatting).

East German citizens expressed their dissatisfaction with housing in ways that reflected the complex relationship between an omnipresent state and the society it sought to govern, manage and control. Citizens did not simply retreat into a "protective community" ("Schutzgemeinschaft") of family and friends nor where they content with the kind of "niche society” popularised in Günter Gaus’s 1983 description of the GDR (Betts, 2010, p. 11; Gaus, 1983). As the historian Paul Betts has shown, there were a number of domains where citizens were able to carve out a modest albeit closely regulated culture of complaint and dissensus. Some turned to the informal dispute commissions (Schiedskommisionen) which were set up in 1963 in residential neighbourhoods to "take pressure off the legal system” and provide a mechanism for resolving minor disputes around noise, disturbances of the peace, vandalism, housing regulation violations, petty quarrels, etc. (Betts, 2010, p. 148, 149). 
Others turned to the system of citizen petitions (Eingaben) which became, in Betts own words, the "best functioning and most used form of communication between citizens and state authorities, offering people without official connections one of the few available avenues to redress wrongs or problems” (Betts, 2010, p. 174).

The right to petition in the GDR was enshrined in Article 3 of the Constitution according to which every citizen was entitled to "turn to the representative bodies of the people, their individual members, or state and economic organisations, with Eingaben (suggestions, tips, requests or complaints” (Mampel, 1982, p. 1312). Eingaben assumed a number of different forms; complaints sent on a monthly basis to ministries and, in some cases, major functionaries in the SED; letters to local and regional representatives; open surgery discussions (Sprechstunden) held by local party officials. Overall, hundreds of thousands of complaints were formally filed every year with the number reaching a million in 1989 (Fulbrook, 2005, p. 374; Betts, 2010, p. 175; see also Mitchell, 2015).

East German citizens complained about a wide range of issues that affected them in their daily lives such as wages, inadequate healthcare, holiday entitlements, childcare, pollution, public transportation, food queues, and, perhaps more than anything else, housing. While some commentators have gone so far as to say the system of Eingaben represented the "main source of uncoordinated resistance to the SED”, others have been more circumspect recognising that the "culture of complaint" that it fostered was predicated on the latent power of a state that could be addressed but never systematically challenged (Zatlin, 2007, p. 315; Palmowski, 2009, p. 311). 
And yet, as in case of the infamous lettres de cachet in Ancien Regime France, the vast system of citizen petitions in the GDR has become an important historical resource offering a "window onto the experience of ordinary lives touched by power” (Luxon, 2016, p. 2; see Farge and Foucault, 2016). For the scholar of the socialist city, they provide a glimpse into the daily rancours and resentments of citizens for whom the limits of permissible resistance were otherwise curtailed. Letters ranged from scribbled handwritten notes to meticulously annotated letters. While many used the system of Eingaben to denounce neighbours, the majority of letters focused on personal material circumstances. As routine reports produced by local authorities showed, it was around housing, more than anything else, that citizens expressed their discontent. In some cases, these were highly personal letters requesting a new flat after marriage or in the wake of a divorce. Most complaints centred, however, on the inadequate and insecure living conditions that many citizens faced in the GDR (Betts, 2010, p. 185).

The rest of this paper is largely based on a close reading of the complaints submitted by East German citizens alongside other archival remainders: housing-related reports produced by local authorities and other government agencies; information gathered by the MfS; and dissident Samisdat literature which, from the 1970s and 1980s onwards, documented the actions of the opposition in GDR including the struggles of squatters in East Berlin and elsewhere. ${ }^{7}$ While there is no single repository of materials devoted exclusively to the history of Schwarzwohnen, a close examination of these 'remainders' points to a minor history of housing that has been largely ignored. The paper draws inspiration, moreover, from recent scholarship in geography that has paid increasing attention to the archive as both a "space of

\footnotetext{
${ }^{7}$ Samisdat is based on the the Russian word for self-publishing and came to be used by dissident circles in the GDR (Samisdat) to describe the production and distribution of subversive texts.
} 
embodied encounter” and a “space of documentary investigation” (Legg, 2016, p. 794, and see Lorimer, 2009; Mills, 2013; Moore, 2010; AUTHOR). This is work that treats the archive as "something in between a set of documents, their institutions, and a repository of memory" (Stoler, 2009, p. 49). In so doing, it utilizes materials that not only harbored the various investments of the state but also registered the wishes and desires - the moments of agency exercised by ordinary citizens whose basic housing needs were unfulfilled. As these materials show, citizens did not simply agitate for better housing, they actively took matters into their own hands.

\section{The Illegal Occupation of Housing in East Berlin}

"We have unlawfully moved into an empty apartment” were the words of a young family (hereafter Family W) who submitted a citizen’s petition to the SED leadership in East Berlin in July 1979. According to the family, the apartment had "not been used since 1970/1. It was dilapidated, in need of immediate repair and an urgent overhaul." "We moved into the apartment," they continued, "because we could no longer endure the condition in which we had to live.” This prevented the family from, in their own eyes, exercising their duty as 'good' citizens of the GDR. As they concluded, “our purpose is to live in dignity so that we can devote our energies to building our state and to giving our child a happy future. The poor conditions we endured meant that this challenge could not be met." 8

Family W. were not alone in asserting their right to housing as citizens of the GDR. Many others, especially in East Berlin and other large cities adopted the practice of illegal squatting

\footnotetext{
${ }^{8}$ LAB, C Rep 902, Nr. 4899, Bezirksleitung der SED, Eingabenbearbeitung durch die Arbeitsgruppe für Staats und Rechtsfragen beim 1. Sektretär der Bezirksleitung der SED, "Legalisierung eines illegalen Bezuges", July 12 , 1979, n.p.
} 
to secure housing that was, in their eyes, increasingly more effective and successful than the official process of allocation which often left them waiting for many years (Kowalczuk, 1992, p. 253). The practice of squatting can be traced back to the late 1960s with the first recorded incident in the city of Halle in 1967 (see Grashoff, 2011a). A few years later, the Mayor's office in East Berlin was already warning that the state was losing “order and control” over the assignment of housing in the city. By the early 1970s, squatting had become widespread across East Germany and, in East Berlin, a series of official briefings were issued that drew attention to a rapid rise in "the illegal occupation of dwellings."9

While it is difficult to paint a full picture of the scale of squatting in the GDR and its geographical distribution, there is considerable evidence to suggest that thousands of ordinary citizens and families were willing to defy authorities and squat dwellings across the country. The most detailed report was compiled in Dresden in November 1984 by a KWV official on behalf of the MfS. The report provided a systematic inventory of empty housing stock in Dresden's Innere Neustadt as well as the number of empty properties that had been illegally squatted. Over 230 empty properties were identified; 17 of which were occupied without permission. ${ }^{10}$ In the case of Berlin, the data remains incomplete. Efforts began in the late 1970s to catalogue the number of empty properties in the city and the process drew attention to a growing number of illegal occupations. The 1980s yielded a more thorough picture. Over 646 cases of squatting were reported in East Berlin in the first six months of 1984; a further 483 apartments were identified for the same period in 1985. Another 1983 report put the number of people illegally occupying buildings in the Berlin district of Prenzlauer Berg alone

\footnotetext{
${ }^{9}$ LAB, C Rep. 100-05, Nr. 1397, Magistrat von Berlin, Büro des Magistrats, Sitzung des Magistrats, "Analyse über die Verwirklichung des Erlasses des Staatsrates der DDR"; LAB, C Rep. 100-05, Nr. 1472,Magistrat von Berlin, Büro des Magistrats, Sitzung des Magistrats, "Eingabenarbeitung, 1. Halbjahr, 1971", September 29, 1971.

${ }^{10} \mathrm{BStU}, \mathrm{MfS}, \mathrm{BV}$ Dresden, AKR Nr: 10070.
} 
at $800 .{ }^{11}$ A few years later, the number had risen to almost 1300 (Grashoff, 2011b, p. 19).

Throughout the 1980s, it is estimated that there were at least 1000 cases per year in East

Berlin. The official statistics point to a scale of squatting that, if anything, rivalled its counterpart in the Western half of the city (see AUTHOR).

The history of squatting in West Berlin is, of course, well-documented as is the role that the state played in pacifying and institutionalizing a movement that had a major impact on housing politics in the city (see Bodenschatz, Heise and Korfmacher, 1983; Holm and Kuhn, 2011; Laurisch, 1981; AUTHOR; AUTHOR). Recent scholarship has also drawn attention to the interventionist nature of the East German State and housing, in this respect, was no exception. As the historian Peter Mitchell (2015) has argued, squatters challenged the relationship of dependency between state and society and the ability of the SED-regime to control and manage the housing needs of its citizens.

The state responded to the rise of illegal squatting through a series of initiatives. Nationally, efforts were made to reduce the number of unlawful occupations while strengthening the official process through which housing was allocated. As occupations rose in the late 1970s, a special commission, the Arbeitsgruppe Wohnungspolitik, was established to counter the growth in illegal squatting. At the same time, local politicians in East Berlin called for new legislative powers. Some even went so far as to suggest that the government-controlled press be used to "mobilize the public against the illegal occupation of living space." 12 While the

\footnotetext{
${ }^{11}$ LAB, C Rep. 111, Nr. 57, Stellvertreter des Oberbürgermeisters für Wohnungspolitik: Information über die Eingaben während der Vorbereitung der Wahlen am 6.5.84, "Ungesetzliche Bezüge im I. Halbjahr 1984"; LAB, C Rep. 100-05, Nr. 1996, Magistrat von Berlin, Büro des Magistrats, "Stand der Erfüllung der Wohnraumvergabepläne der Räte der Stadtbezirke per 21. Aug. 1985 », October 2, 1985; LAB, C Rep. 134-0202, Nr. 1358, Rat des Stadtbezirkes Prenzlauer Berg, Ratsitzung am 21.11.1985, "Ungeklärte Mieteingänge per 1.1.1985", n.p.

12 SAPMO, DY30/22387, Magistrat von Berlin, Der Oberbürgermeister, “Dienstanweisung zur Bekämpfung des ungesetzlichen Bezuges von Wohnraum in Berlin", April 20, 1983.
} 
actions of squatters were routinely monitored by the MfS, the security organs paid relatively little attention to squatting per se and focused their efforts on the actions of specific squatters who posed, in the eyes of the regime, a threat to its dominant ideologies (see Mitchell, 2015, p. 247, 259).

In the end, efforts by the East German state to control squatting were piecemeal and pragmatic reflecting in the words of one commentator, “a permanently overburdened bureaucracy” unable to meet the needs of its citizens (Grashoff, forthcoming). At the local level, authorities lacked the resources and, in many cases, the willingness, to impose and enforce existing legislation. Many focused their attention on reducing the period in which properties stood vacant. Hygiene inspectors were, in turn, instructed to disconnect utilities in buildings that were no longer fit for human habitation. At the same time, state officials were reluctant to carry out evictions as squatters often took pressure off growing waiting lists and returned dilapidated housing stock into use. As the right to housing was enshrined within the GDR's 1949 constitution, authorities also tended to avoid forced evictions as they would otherwise be legally required by the Zivilgesetzbuch to provide alternative housing for squatters, many of whom had no other options. In response, authorities often resorted to fines ranging from 50 to $500 \mathrm{M}$ though there is insufficient evidence to gauge how many citizens were ultimately fined though squatters in Berlin found that local authorities were more likely to issue penalty charges in Prenzlauer Berg than in the neighbouring district of Friedrichshain (Grashoff, 2011b, p. 101). ${ }^{13}$ Unsurprisingly perhaps, the files of municipal authorities across the GDR were also full of denunciations by neighbours who contacted the authorities to inform them of illegal occupations though the chances of remaining in properties remained

\footnotetext{
${ }^{13} \mathrm{An}$ article in the Instand-Besetzer-Post talks of fines of $300 \mathrm{M}$. See Papier Tiger Archiv (hereafter PTA), Instand-Besetzer-Post, 19.6.1981, p. 6
} 
relatively high.

\section{'Makeshift' Socialisms}

Squatting in the GDR was characterised by a complex process of adaptation and negotiation that operated at the margins of legality and formality (see Holston 2008). While it would be tempting to read this history through existing scholarship on squatting and urban informality, this paper urges caution in this respect. It argues that the actions and practices adopted by squatters in East Germany and East Berlin, reflect a unique phenomenon that has significant implications for the study of the socialist city not to mention work on the nature of postsocialist urban transformation (Ferenčuhová, 2016; Ferenčuhová and Gentile, 2016; Grubbauer, 2012). But more than this, it also suggests that a thick description of squatting in the GDR has the potential to re-centre and extend the use and applicability of concepts that have animated recent urban scholarship in both the global North and South. This applies as much to the question of informality as it does to the makeshift practices adopted by East German squatters or the wider political implications of the tactics that they developed (Grashoff, forthcoming). At stake here, is a reading of housing insecurity that seeks to challenge a particularist understanding of squatting in favour of an approach that recognises its broader conceptual and empirical significance.

It would be misleading, therefore, to situate the actions of squatters in East Berlin within a conspicuously Western framework shaped by the predations of capitalist urban development. Squatters in the GDR were not involved in a major (and often violent) struggle over housing (Häuserkampf) nor did they - for the most part - see themselves as part of a single, cohesive movement or the spaces they occupied as a bridgehead for articulating anti-capitalist forms of 
political agency. In the East, squatters described their own version of illegal occupation as Schwarzwohnen. There is no easy translation of the term but its meaning can be gleaned from a cluster of related words including 'schwarzfahren' ('fare dodging') and 'Schwarzmarkt' ('black market'). Many squatters in East Berlin also used the term 'wohnungsbesetzen' ('occupying apartments’) or 'stilles besetzen’ ('clandestine or covert squatting’) (see Mitchell, 2015, p. 5).

For former squatters in the East, Schwarzwohnen spoke to a desire to take control of their own lives and respond to basic housing needs (in most cases squatters did pay some form of rent). According to Grashoff, "political protest [...] hardly played a role. People wanted to have a home of their own. Illegal occupation was an expression of individual self-help in the face of the State's inability to fulfil its own promises on adequate housing for all” (2011a, p. 5). As one former Schwarzwohner recollected, “we lived in squats and did not understand why such a fuss was made in Kreuzberg with banners and demonstrations. To squat had little political resonance. We simply needed the space” (Felsmann and Gröschner, 2012, p. 15). They were supported by another squatter who pointed out that, "[Schwarzwohnen] was not a political movement. We had no programme, no overarching concept, just a happy coexistence. All of it just happened [...] We did not squat houses, it was not a political act nor an act of aggression or an act of provocation. It was all quite natural. There was free living space and so we took it. That was ‘Schwarzwohnen’ - a typical East German practice that no longer exists today” (quoted in Grashoff, 2011b, p. 11).

As a 'typical practice', Schwarzwohnen belongs to a socialist history that was circumscribed in both space and time and marked by its abrupt end. It was also part of a wider spectrum of informal housing practices that stretched across the ‘actually existing socialisms’ of Central 
and Eastern Europe where housing was in "perpetual short supply” (Nuga et al. 2016: 868; see Szelényi, 1983; Zegarac, 1999). As a number of studies have shown, this encompassed a range of informal arrangements from the occupation and communal use of dilapidated tenements in inner-city districts to the construction of socialist summerhouse settlements (including dachi) on the peri-urban fringe (see Lovell, 2003; Nuga et al, 2016). While Schwarzwohnen may have, in other words, represented a local response to substandard living conditions, it was, symptomatic of a much wider ecosystem of housing insecurity that helped to shape the nature of urbanity in socialist cities despite the efforts of the state to supress marginality and informality (see Hirt, 2013: s34). At the same time, Schwarzwohner in the GDR adopted a makeshift form of urbanism that also served as a point of reference that reflected, in many ways, the actions of their counterparts in the capitalist West not to mention the tactics mobilised by city-dwellers across the global South (see AUTHOR; Pieterse and Simone, 2017). The properties occupied by Schwarzwohner often relied on similar do-ityourself practices that gradually transformed squatted flats into liveable spaces and that were, in turn, a product of a wider shadow economy based on practices of informality and reciprocity.

Local authorities in East Berlin and other cities in the GDR lacked the resources to carry out the most basic of repairs and there was a serious shortfall in skilled labourers and tradesmen, in particular bricklayers, locksmiths, joiners and plumbers. ${ }^{14}$ Community centres offered access to tools and materials as well as a range of training course though, as was the case in other parts of the Eastern bloc, a parallel 'grey economy' emerged that compensated for the inadequacies and scarcities of the state-planned system (Kreis, 2018). People organised their

\footnotetext{
14 LAB, C Rep. 143-02-02, Nr. 1251, Ratbeschlüsse Prenzlauer Berg, Ratsitzungen, “Information über den erriechten Stand in der Arbeit mit Hausreparatur pluanen in der Wohnraumwerverhaltung", February 24, 1982, n.p.
} 
own networks of goods and services and, in turn, undertook household repairs using tools and supplies that they had sourced through a well-established barter economy (Betts, 2010, p. 184; Harsch, 2018). "We never owned anything that might be of value to others,” one Schwarzwohner later noted, "most of our antique goods came from garbage containers” (Felsmann and Gröschner, 2012, p.15).

When the photographer Tina Barra and others squatted a house at 7 Fehrbelliner Straße, they found that the "roof was broken and the apartment block had been cleared by housing officers." "We had chosen," she added,

The summer holidays, since the authorities were, according to our own experience, a bit sluggish and not very efficient [...] It was a while before someone in the local housing office found out that we had moved in. As punishment, we were not able to secure a rental agreement. Rather we obtained a special license that stated that the authorities were no longer responsible for the apartment and that we had to do all the repairs ourselves [...] We tried our best to do makeshift repairs [...] There was no bathroom and our attempts at heating were adventurous to say the least (quoted in Felsmann and Gröschner, 2012, p. 39).

Other squatters reported similar experiences. Ulrike Poppe, one of the founders of the “Women for Peace” (“Frauen für den Frieden”) group, recalled living in a ground floor flat on Wilhelm-Pieck-Straße: "it consisted of one room, a kitchen and an outside toilet as was the case for many. Three walls were covered in damp, and there was as good as no natural light” (Felsmann and Gröschner, 2012, p. 306). The journalist and writer, Annete Gröschner described, in turn, her first flat on Schönhauser Allee as a dark "cave.” "The floorboards were 
rotting and the oven had rusted through. But the worst part was the outdoor loo. The door had fallen off $[\ldots]$ and I had to use the now demolished toilet at the U-Bahn stop” (Felsmann and Gröschner, 2012, p. 433). As another squatter in a special report in the Instand-Besetzer-Post on the East Berlin squatting scene concluded, “without a bottle of schnapps, you would freeze your ass off.”15

Schwarzwohner were nevertheless successful in rescuing and restoring many older buildings and, in their own way, managed to offer a modest alternative to the official modernist paradigm favored by SED leaders (Grashoff, forthcoming). Floorboards, pipes and windows were replaced, roofs were repaired, and courtyards were transformed into small community playgrounds (see Grashoff, 2011b, p. 76-83). And yet, while the preoccupation with mending, repair and self-help highlighted the degree to which squatters re-claimed the home as a site of individual freedom, the very act of re-appropriation and renovation was also widely used as a negotiating tactic with local authorities. In many cases, authorities tacitly accepted the existence of illegal occupations arguing that they ensured that buildings were occupied and in relatively good condition. In some cases, housing officers were even willing to grant temporary licenses to squatters (what was known as an “Ausbauvertrag” or “renovation contract”) so long as they agreed to undertake and finance repairs. This was later formalized and rolled out in East Berlin in 1979 as a new policy to shorten waiting lists and address growing levels of vacancy (Mitchell, 2015, p. 270).

The makeshift version of the socialist city cultivated by Schwarzwohner thus provides a rather different example of the kind of “fragment urbanism” recently examined by Colin McFarlane (forthcoming). McFarlane's own focus is on the global South and the growing

15 PTA, Instand-Besetzer-Post, 19.6.1981, p. 6 
number of residents who have come to experience the city as a "geography of shards and fragments” (Roy, 2015, p. 7). For scholars working in East Germany and, for that matter, other former socialist states in Central and Eastern Europe, the question of fragmentation is better understood in relation to the spatial regime that the state attempted to impose on its citizens and "upon which authorities could map out their dominant ideologies and organise society along its preferred lines". Life under "really-existing socialism” was always less than harmonious and the social fabric remained contested and fragmented (Hayton, 2016, p. 355; see also Betts, 2010; Fulbrook, 2005; Mitchell, 2015). This applied, in particular, to the provision of housing and the derelict or inadequate buildings that many residents encountered and, in the case of Schwarzwohner, chose to occupy, repair and maintain. By attending to these fragments, their actions pointed to other ways - however modest, makeshift and informal - of organising socialist space and the home.

The form of fragmentation mobilized and re-purposed by many Schwarzwohner should not, however, be seen as an exclusive source of political action and dissent. Some commentators have suggested that the practice of occupation reflected what German historians of everyday life (Alltagsgeschichte) have elsewhere described as an assertion of re-appropriation, selfreliance or self-will (“Eigensinn”) (see Lüdtke, 1995). Others including Udo Grashoff (2011b; forthcoming) have adopted a different approach to the question of agency highlighting the informal practices of Schwarzwohner and the fluid relationship that many had with a state that was unable to impose its authority on the allocation and management of housing.

Within urban studies, it is widely accepted that "informality is best approached as a set of practices that exist in relation to, rather than outside of, the formal city” (Iveson et al, 
forthcoming: 3). The literature on informal housing is well developed and recent efforts to 'decouple' informality from cities in the global South may find, in the socialist city, another useful point of reference. As already noted, it was quite common for squatters in East Berlin and elsewhere to seek to formalize their living arrangements. Some were willing to accept the risks that accompanied squatting though many others were keen to register with the authorities in order to secure a tenancy agreement. It was believed by many Schwarzwohner that they simply needed to pay rent and utilities (usually for three to six months) or receive a certificate from the Volkspolizei to regularize their status. “After six months you'd go to the Communal Housing Association,” explained one former squatter, the poet Peter Wawerzinek. “Normally,” he continued, “you'd receive no more than a fine, and then you were safe and secure in your apartment (Felsmann and Gröschner, 2012, p. 366).

This wasn't legally the case, however, and the unlawful use of housing led to various administrative penalties and fines and, in some cases, the forced removal of squatters though authorities were reluctant to carry out evictions that would put additional stress on the housing system. The number of forced evictions reported in East Berlin were relatively low. One 1984 report noted that, in the first half of the year, over 640 instances of unauthorized occupation were recorded of which roughly a hundred resulted in an eviction. In the previous year, only 88 forced evictions were carried out across the city. ${ }^{16}$ As the mayor's office had already concluded in 1980, “an eviction is not possible in the majority of cases, because these citizens do not possess a home of their own.”17

\footnotetext{
${ }^{16}$ LAB, C Rep. 111, Nr. 57, Stellvertreter des Oberbürgermeisters für Wohnungspolitik: Information über die Eingaben während der Vorbereitung der Wahlen am 6.Mai 1984, "Ungesetzliche Bezüge im 1. Halbjahr 1984", July 13, 1984, p. 9; LAB, C Rep. 100-05, Magistrat von Berlin, Büro des Magistrats, Nr. 1945/1, "Eingabenanalyse 1983", pp. 7-8.

${ }^{17}$ LAB, C Rep. 100-05, Nr. 1837, Magistrat von Berlin, Büro des Magistrats, “Maßnahmen zur Senkung der Leerstandzeiten von Wohnungen", September 24, 1980.
} 
At the same time, petitions (Eingaben) submitted by residents in East Berlin and elsewhere also provided a rare glimpse into a much wider spectrum of informal practices and tactics used by citizens in response to housing insecurity and scarcity. One of the most popular tricks was to move into a property as a sub-tenant just before the main tenant had either moved or passed away and to carry on living there illegally without informing the local office of the KWV (Mitchell, 2015, p. 108). Requests to swap apartments were regularly received by authorities. Some local housing officers in East Berlin were even accused of acting on behalf of squatters by providing them with information about empty housing and, in one particular dispute, unlawfully issuing keys to an apartment. ${ }^{18}$

As an archive of housing insecurity, the Eingaben produced by Schwarzwohner ultimately represented a set of unauthorised and informal practices that offered an alternative to the state's monopoly on housing and the understanding of urban space it presumed. These were practices that, on the one hand, showed a willingness to push the boundaries of acceptable dissent and resistance. On the other hand, they also demonstrated an appreciation of the limitations that squatters faced and a recognition of the uneven field of power in which their actions took place. In other words, while recent research on informal settlements in the global South has highlighted how "citizen practice is itself constitutive of state form” (Ghertner, 2017; emphasis added), the actions of Schwarzwohner served, in many ways, to reinforce the East German state’s ability to shape society. Many squatters understood their actions as a means to exercise their rights as 'good' citizens and were more than willing "to conform to the law, to pay rent and to renovate their flats at their own expense” (Grashoff, forthcoming). Informality, in their eyes, was less an act of political defiance than a process or tactic to secure housing.

${ }^{18}$ Lab C, Rep. 903-01-07, Nr. 1169, “Zur Erfassung und Auswertung der Eingaben von Frau W”, 1985, n.p. 
It would nevertheless be misleading to conclude that Schwarzwohnen was apolitical. Squatters were, after all, able to carve out a space from the regime and "repurpose it for alternative ends” (Hayton, 2016, p. 355). For Paul Betts, it was in fact the private sphere and the everyday geographies of the home that became, in the GDR, an arena of autonomy, selfexpression and potential dissent. "State socialism," he writes, "may have severely curtailed the limits of permissible talk, patrolling the borders of public discourse as much as it policed its state borders” (2010, p. 15). But people, according to Betts, were also determined to construct and stage a private sphere for various purposes and, in some cases, that sphere was itself part of a wider network of opposition and dissent.

\section{Infrastructures of Dissent in East Berlin}

On the evening of November 15, 1985, the West German broadcaster ZDF ran a feature on the “Today Journal” by their East Berlin-based correspondent Werner Brüssau. The feature focused on the forced eviction of Frau T. and her three children from an apartment on Metzer Straße in Berlin-Mitte which they had been illegally occupying since September. The apartment had been recently renovated and a new tenant had already been allocated to the flat. Frau T. refused, however, to vacate the apartment. She was offered alternate housing and additional assistance by local authorities in the Department of Housing. Frau T. chose to stay and submitted a petition to the Mayor's office. A detailed assessment of her case was filed and it was determined that she and her family would be evicted on November 15, 1985. It was at this point that Frau T tipped the ZDF who dispatched a team to film the eviction. ${ }^{19}$

\footnotetext{
${ }^{19}$ BstU, MfS, ZAIG, Nr. 15297.
} 
Unlike most negotiations between Schwarzwohner and the authorities, the actions of Frau T. were unusually bold and singular in their defiance of the state. Public acts of squatting were largely eschewed though political imperatives began to play a growing role in the action repertoire adopted by East German squatters in the 1980s. These were practices that contributed to "the emergence of social and cultural practices which undermined the authority of the regime in the 1980s” (Hayton, 2017, p. 355). One former activist, Wolfgang Rüddenklau, described a new infrastructure of dissent in which squatting played a growing role. "The islands of occupied flats and houses," he later wrote, "grew together to form an alternative social structure. They affirmed a self-determined lifestyle and developed a common culture” (quoted in Moldt, 2005, p. 7).

Rüddenklau himself lived for many years in a squatted house in Prenzlauer Berg at Fehrbelliner Straße 7. The house was widely known as a central space of oppositional activity in East Berlin and was described by the security services as a "non-conformist centre for resistance” (Hayton, 2017, p. 370). Tina Bara, another former resident of the same house, recalled her four years “in the Fehrbellinerplatz”. “A pretty wild mixed bunch of people lived there,” she noted, "our apartment was a meeting place [...] especially for those in the illegal environmental movement. People constantly came to see us. Appointments and plans were made and projects forged” (Felsmann and Gröschner, 2012, p. 40).

The squat at Fehrbelliner Straße 7 and other alternative spaces in East Berlin played an important role in the development of a distinct ecology of protest - social, cultural and political - that emerged in East Berlin in the 1970s and 1980s and that was centred on the district of Prenzlauer Berg. While dissident groups were scattered across the city, it was the neighbourhood with the highest concentration of groups involved in "state-independent 
political activities.” This included groups such as "Women for Peace” (“Frauen für den Frieden”), “The Initiative for Peace and Human Rights” (“Initiative für Frieden und Menschenrechte”) and “The Environmental Library” (“Umwelt-Bibliothek”) (Glaeser, 2011, p. 345-346).

While traditional accounts of the German Democratic Republic emphasised its “apparent stability, efficiency and political quiescence”, recent historical scholarship has drawn attention to "the pervasiveness of political insubordination" throughout the history of the GDR. Until the 1980s - and with the exception of the June Uprising of 1953 - public expressions of mass discontent played little role in the emergence of oppositional forms of political action in the GDR. Minor and largely inconspicuous acts of resistance were commonplace throughout the 1950s and 1960s even if they were relegated to the "interstices of East Germany society” and subsisted alongside well-worn patterns of conformity and retreatism. What changed in the late 1970s and early 1980s was the development of wellorganised networks of dissent pursuing modest goals that were compatible, in the eyes of many, with the goals of 'existing socialism' (Fulbrook, 1993, p. 265, 266, 278).

The more politically active spaces cultivated by some East German squatters must be seen in this context. The same spaces also began to attract the attention of the Western press. A series of exposés appeared in the early 1980s documenting a small but thriving set of youth subcultures that included a vibrant punk music scene that had found a home in the city's squatted apartments (see Hayton, 2013). If these articles sought to capture an underground scene that existed on the margins of mainstream GDR society, they also highlighted a growing willingness by many young people to express their dissatisfaction in public. Even graffiti more commonly associated with the West German squatting scene - "Legal, illegal, 
scheissegal!” (“legal, illegal, who gives a fuck!”) - began to feature on walls in East Berlin (Wensierski and Büscher, 1983, p. 119).

As the historian Jeffrey Hayton has argued, the punk scene offered a different understanding of space that questioned "the authority and legitimacy of the SED [regime]" (2013, p. 548) and sparked a major crackdown by the MfS. Squats were raided on a number of occasions though activists still found ways to express their dissent. In September 1988, an anonymous report appeared in the East German underground magazine Umweltblätter describing the plight of a group of squatters who had occupied Lychener Straße 61 in the Berlin district of Prenzlauer Berg. In the squatters own words, they had "occupied the house in order to overcome the contradiction between, on the one hand, the many vacant and decaying houses [in Berlin], and on the other, a growing number of people in search of housing.” As “squatters (Instandbesetzer),” they proclaimed, “we will resist the further cultural and spiritual devastation of the country." ${ }^{20}$ Not only did the occupants of the house see themselves as part of a wider community but their use of a West German term for squatter (Instandbesetzer) hinted at a scene that increasingly understood their actions in clear political terms. The magazine in which the article appeared, the Umweltblätter, represented one of the most important and widely distributed Samisdat publications in East Germany during the 1980s. It was published by the Umwelt-Bibliothek, an independent information centre that was founded by a group of environmental activists in the basement of the Zionskirche meeting hall in Berlin in September 1986.

Like their counterparts on Fehrbelliner Straße, the occupants of Lychener Straße 61 were subject to routine police raids and the eventual eviction and demolition of the house in

${ }^{20}$ RHG, Umweltblätter, Nr. 4, p. 2. 
September 1988 was greeted by an unusually open display of resistance by the occupants who unfurled a banner from the roof of the house proclaiming that "this house has been ruined by the KWV.”21 Most Schwarzwohner were less brazen, however, than the squatters on Lychener Straße and their efforts to live independently were largely tolerated. The MfS were far more concerned with the punk scene in the GDR and its connections to a wider network of activists in the peace and environmental movements. While the full weight of the state was mobilised to undermine the political impact of punk, squatting itself was never seen as an existential threat to the GDR (Hayton, 2013, p. 544). In the eyes of the regime, it remained an ambivalent practice that not only challenged the authority of the state. It provided, at the same time, an informal mechanism for alleviating a crisis in housing that administrators were ultimately unable to address.

The growing politicisation of squatting in the 1980s only served to reinforce widespread dissatisfaction with the state of housing in the GDR and the SED regime in general. The number of citizen petitions related to housing rose in the months leading up to the collapse of the GDR in 1989 and “the desolate state of East Germany’s cities presented”, in the words of two activists, "perhaps the most visible symbol of the social, economic and cultural incompetence of the GDR’s leadership” (Jordan and Kloth, 1995, p. 297). And yet, the 'housing question' has remained conspicuously absent from recent scholarship on the dramatic explosion of large-scale collective action in 1988 and 1989 that ultimately undermined the regime’s stability (Pfaff, 2006, p. 12).

For squatters, the fall of the Berlin Wall in November 1989 and the rapid dismantling of the

${ }^{21}$ RHG, Umweltblätter, October 1988, p. $2 \mathrm{f}$. 
East German state apparatus proved contradictory. On the one hand, the abrupt end of the GDR and the rapid wholesale adoption of a new institutional order helped dictate the transition from a socialist to post-socialist urban context which was, in turn, characterised by a new spatial fix and the emergence of a capitalist housing sector in which professional housing companies and developers played a decisive role (see Bernt, 2016, p. 578). There was little room, so it seemed, for Schwarzwohner within the agenda for urban renewal in East Berlin. On the other hand, as Andrej Holm and Armin Kuhn have also argued, it was "the political power vacuum of the Wende period, and the massive loss of authority on the part of the police and municipality” that led to the large-scale occupation of vacant old buildings in East Berlin (2011, p. 649). During the final months of 1989 and early 1990, over 130 houses were occupied by squatters in the inner-city districts of Mitte, Prenzlauer Berg, Friedrichshain and Lichtenberg. The wave of occupations came to an abrupt end, however, with the violent eviction of squatters on Mainzer Straße in November 1990 in a brutal police operation (AUTHOR).

The history of the squatting scene in the former East has been widely documented and should be seen, in the context, of a much wider transformation of urban space (see AUTHOR). Squats - some of which were later legalised - were often enrolled in a programme of renovation that provided direct public subsidies for the preservation of existing housing stock and the social structures they supported (Bernt, 2017, p. 579). Over the course of the 1990s, these subsidies were phased out in favour of a more aggressive and market-driven form of urban regeneration and gentrification. The displacement of low income tenants accelerated while alternative housing projects became increasingly isolated especially as funding for social housing was withdrawn and existing units across the city were privatised. Rising rents coupled with changes to state benefits only served to intensify the pressures that many 
households in the city faced (Holm, 2014). It is with these developments in mind and the broader 'housing question' that they point to that the paper offers some concluding observations on the recent evolution of housing insecurity in Berlin.

\section{Conclusion}

The overarching aim of this paper is to reconstruct the history of illegal occupation and squatting in East Berlin. What was commonly known as "Schwarzwohnen” involved thousands of citizens living across the GDR who chose to defy the authorities and take control of their own housing needs. In the face of inadequate housing, Schwarzwohner adopted, as this paper argues, a number of informal and makeshift tactics for securing and, in many cases, building a home. These were tactics that, on the one hand, recognised the omnipresence of the state and the challenges that squatters faced in negotiating an uneven field of power in which their agency was greatly diminished. On the other hand, they also pointed to - and increasingly shaped - an emerging sphere of dissent and resistance in the final years of the GDR. The history of Schwarzwohnen traced in this paper, however, should not be seen as another supplementary chapter in a broader history of housing insecurity and urban squatting nor should it be viewed from an exclusively Western point of view. If German unification marked an abrupt and disorientating end to the GDR, this also applied to the actions and practices of Schwarzwohner whose disappearance in the years following the fall of the Berlin Wall was equally sudden. As geographers and historians of the GDR have argued, the everyday realities of a socialist past now appear "dislocated, disembodied and out of context” and, as such, pose unique conceptual and historiographic challenges not least for

many East Germans who have “defended their lost communist world with surprising passion and even longing” (Bach, 2017, p. 5; Betts, 2010, p. 228). 
At the heart of this paper is an attempt to acknowledge and address the critical problem space that these challenges produce. While squatting may have briefly flourished in East Berlin in the immediate aftermath of the collapse of the GDR, many of the housing projects that survived and were able to secure legal licenses in the early 1990s have either been cleared or face eviction. The emergence of this 'movement' - however brief and intense- is well-known and it is often plotted in relation to an earlier history of struggle in the Western half of the city. This is a history which has served as an important point of reference not least for Western activists who squatted in the East in increasingly large numbers after the fall of the Wall (see AUTHOR). And yet, any attempt to compare these two histories has tended to overlook the history of housing struggles during “actually existing socialism”. As Michael Gentile has recently argued in a related context, the socialist past is "frequently [...] described in a sketchy, sweeping and inexact manner”. According to Gentile, this has significant implications for the ways in which we come to think about and research the 'postsocialist city.' "For our understanding," he writes, “of what actually was under socialism is still incomplete [...] the 'socialist' in the 'post-socialist city' is possibly the latter concept's weakest link” (forthcoming)

This paper offers one potential response to Gentile’s remarks. By placing particular emphasis on the actions of Schwarzwohner in East Berlin, the paper seeks to draw attention to the practices they adopted on the terms in which they were originally articulated. These are practices that undoubtedly reflect a much wider body of urban theory-making. But they also point to practices - informal, makeshift, and precarious - that were immanent to the realities of city-dwellers in the GDR. Housing, after all, was a major source of dissatisfaction and many East German citizens chose to take matters into their own hands. While the practices they cultivated and the spaces they created may have receded from view, they remain part of 
an extensive archive of alternative knowledges, materials and resources that, taken together, remain an important point of reference for housing struggles in contemporary Berlin.

This is a history of struggle that speaks, in turn, to wider conceptual concerns. At stake here, is the articulation of an historically grounded approach to housing insecurity and urban squatting that ultimately seeks to re-calibrate our understanding of the socialist city and its (largely) peripheral place within urban theory. In so doing, the paper makes three major claims that have wider implications for how we come to think about and research cities that have experienced socialism. These are:

1) A focus on the history of Schwarzwohnen in East Berlin underscores the need for historically nuanced accounts of housing insecurity. In the case of the 'socialist city', this is an optic that has the potential to challenge the limited role that the socialist era has traditionally played in accounts of post-socialist urban transformation. A commitment to re-thinking the nature of the post-socialist city is dependent, in other words, on a methodological attitude that is "informed by the histories and practices of particular places” rather than a pro forma reading of these places as seen through the lens of “economic transition, marketization or neo-liberalization” (Gentile, forthcoming; see Tuvikene et al., 2017).

2) A recognition of the diverse patterns of political protest adopted by city-dwellers in settings of intense repression and surveillance. There is, of course, a danger in romanticising the activities of Schwarzwohner in an enclosed dictatorship. It is equally important, however, to understand what the structures and experiences of life were like for East Germans who attempted to carve out their own alternative version 
of “actually existing socialism” (Fulbrook, 2005, p. ix). For many East Germans, the city became a site for the articulation of modes acts of dissent, obstinacy and refusal and which, in turn, require new ways of thinking about the relationship between politics and the socialist city.

3) And perhaps most importantly, a conceptual openness to read theories beyond the Western norms on which they are almost exclusively based. This is not a plea for local forms of urban theory but a call to extend and re-function concepts that also emerged in relation and often in counterpoint to tendencies and trajectories that have played an important role in the development of 'Western' urban studies. While others have focused on the distinctiveness of the 'socialist city' (Hirt, 2013), the main focus here is on generating a more expansive historical anthropology of the makeshift and the informal.

Taken together, these orientations, more than anything else, highlight the importance of struggles over housing in East Berlin and the role that the 'housing question' played in shaping the modest forms of protest, adaption and resistance that emerged in relation to and despite the exactions of state socialism. Many East Germans chose to resist the poor housing conditions that they faced and their actions not only laid the groundwork for the struggles that erupted in the Eastern half of the city in the winter of 1989 but they also provided a platform for the development of a wider infrastructure of housing activism in the city that still exists today. 


\section{REFERENCES}

\section{Archival Sources}

Bundesarchiv Berlin (SAMPO)

Bundesbeauftragten für die Unterlage des Staatssicherheitsdienstes der ehemaligen

Deutschen Demokratischen Republik (MfS)

Landesarchiv Berlin (LAB)

Papiertiger Archiv (PTA)

Robert-Havemann-Gesellschaft Archiv (RHG)

\section{Published Sources}

Author

Author

Author

Bach, Jonathan (2017). What remains: Everyday encounters with the socialist past in

Germany. New York: Columbia University Press.

Bernt, Matthias (2016). How post-socialist is gentrification? Observations in East Berlin and Saint Petersburg. Eurasian Geography and Economics, 57(4-5): 565-587. 
Betts, Paul (2010). Within walls: Private life in the German Democratic Republic. Oxford: Oxford University Press.

Bodenschatz, Harald, Heise, Volker \& Korfmancher, Jochen (1983). Schluss mit der Zerstörung? Stadterneuerung und stadtische Opposition in West-Berlin, Amsterdam und London. Wetzlar: Anabas.

Buck, Hannsjörg (2004). Mit hohem Anspruch gescheitert: Die Wohungspolitik der DDR. Munster: Lit Verlag.

Buck, Hannsjörg, and Reuter Ute (1991). Das Scheitern des SED-Wohnungsbauprogramms. Bonn: Gesamtdeutsches Institut.

Coché, Stephanie (2017). Power and society in the GDR: Involuntary psychiatric commitment, 1949-1963. Central European History, 50(2): 218-235.

Farge, Arlette \& Foucault, Michel (2016). Disorderly families: Infamous letters from the Bastille archives. Minneapolis: University of Minnesota Press.

Felsmann, Barbara \& Gröschner, Annette (Eds). (2012). Durchgangszimmer Prenzlauer Berg: Eine Berliner Künstlersozialgeschichte der 1970er und 1980er Jahre in Selbstauskünften. Berlin: Lukas Verlag.

Ferenčuhová, Slavomíra (2016). Explicit definitions and implicit assumptions about postsocialist cities in academic writings. Geography Compass, 10(12): 514-524. 
Ferenčuhová, Slavomíra \& Gentile, Michael (2016). Introduction. Post-socialist cities and urban theory. Eurasian Geography and Economics, 57(4-5): 483-496.

Führer, Karl Christian (1995). Managing scarcity: The German housing shortage and the controlled economy, 1914-1990. German History, 13(1): 326-354.

Fulbrook, Mary (2005). The people's state: East German society from Hitler to Honecker. New Haven: Yale University Press.

Gaus, Günter (1983). Wo Deutschland liegt: Eine Ortsbestimmung. Hamburg: Hoffmann \& Campe.

Gentile, Michael (forthcoming). Three metals and the 'post-socialist city’: Reclaiming the peripheries of urban knowledge. International Journal of Urban and Regional Research.

Ghertner, Asher (2017). When is the state? Topology, temporality and the navigation of everyday state space in Delhi. Annals of the American Association of Geographers, 107(3): 731-750.

Glaeser, Andreas (2011). Political epistemics: The secret police, the opposition and the end of East German socialism. Chicago: University of Chicago Press.

Grashoff, Udo (2011a). Leben im Abriss: Schwarzwohen in Halle an der Saale. Halle: Hasenverlag. 
Grashoff, Udo (2011b). Schwarzwohnen: Die Unterwanderung der staatlichen

Wohnraumlenkung in der DDR. Göttingen: V \& R Unipress, 2011.

Grashoff, Udo (forthcoming). Cautious occupiers and restrained bureaucrats:

Schwarzwohnen in the German Democratic Republic. Somewhat different from squatting. Urban Studies.

Harsch, Donna (2018). Revenge of the domestic: Women, the family, and communism in the German Democratic Republic. Princeton: Princeton University Press.

Hayton, Jeffrey (2013). 'Härte gegen Punk’: Popular music, Western media and state response in the German Democratic Republic. German History, 21(4): 523-549.

Hayton, Jeffrey (2017). Crosstown traffic: Punk rock, space and the porosity of the Berlin Wall in the 1980s. Contemporary European History, 26(2): 353-377.

Hirt, Sonia (2013). Whatever happened to the (post)socialist city? Cities, 32 (S1): S29-S38.

Holm, Andrej (2014). Mietenwahnsinn: Warum wohnen immer teurer wird und wer davon profiteirt. Munich: Knaur.

Holm, Andrej \& Kuhn, Armin. (2011). Squatting and urban renewal: The interaction of squatter movements and strategies of urban restructuring in Berlin. International Journal of Urban and Regional Research, 35: 644-658. 
Holston, James. (2008). Insurgent citizenship: Disjunctions of democracy and modernity in Brazil. Princeton: Princeton University Press.

Iveson, Kurt et al. (forthcoming). The informal Australian city. Australian Geographer.

Jessen, Ralph (1995). Die Gesellschaft im Staatssozialismus. Probleme einer Sozialgeschicte der DDR, Geschichte und Gesellschaft, 21(1): 96-110.

Jordan, Carlo, \& Hans Michael Kloth, (eds.) (1995). Arche Nova: Opposition in der DDR. Berlin: Basis Druck Verlag.

Kadir, Nazima (2016). The autonomous life: Paradoxes of hierarchy and authority in the squatters movement in Amsterdam. Manchester: University of Manchester Press.

Kocka, Jürgen (1994). Eine durchherrschte Gesellschaft. In Hartmut Kaeble, Jürgen Kocka and Hartmut Zwahr, Sozialgeschichte der DDR (pp. 547-553). Stuttgart: Klett-Cotta.

Kowalczuk, Ilko-Sascha (1992). Historische Streiflichter zu Wohnungsnot und Widerstand in Berlin. In Susan Arndt, Stephan Bialas and Grit Friedrich, Berlin, Mainzer Straße. 'Wohnen ist wichtiger als das Gesetz’ (pp. 231-259) Berlin: Basisdruck.

Kreis, R. (2018). A ‘call to tools’: DIY between state building and consumption practices in the GDR. International Journal for History, Culture and Modernity 6: 49-75. 
Laurisch, Bernd. (1981). Kein Abriß under dieser Nummer: 2 Jahre in der Cuvrystraße in Berlin-Kreuzberg. Giessen: Anabas.

Legg, Stephen. (2016). Empirical and analytical subaltern space? Ashrams, brothels and trafficking in colonial Delhi. Cultural Studies, 30(5): 793-815.

Lindenberger, Thomas (Ed.). (1999). Herrschaft und Eigen-Sinn in der Diktator. Studien zur Gesellschaftsgeschichte der DDR. Cologne: Böhlau.

Lovell, Stephen (2003). Summerfolk: A history of the Dacha, 1710-2000. Ithaca, NY: Cornell University Press.

Lüdtke, Alf (Ed.). (1995). The history of everyday life: Reconstructing historical experiences and ways of life. Princeton, NJ: Princeton University Press.

Luxon, Nancy (2016). Editor’s introduction. In Arlette Farge and Michel Foucault, Disoderly families: Infamous letters from the Bastille archives (pp. 1-16). Minneapolis, MN: University of Minnesota Press.

Mampel, Siegfried (1982). Die Sozialistische Verfassung der Deutschen Demokratischen Republik: Kommentar. Frankfurt/M: A. Metzner.

McFarlane, Colin. (forthcoming). Fragment urbanism: Politics at the margins of the city. Environment and Planning D: Society and Space. 
Mills, Sarah (2013). Cultural-historical geographies of the archive: Fragments, objects and ghosts. Geography Compass, 7(10): 701-713.

Mitchell, Peter (2015). Contested space: The history of squatting in divided Berlin, c. 1970c.1990. Unpublished PhD, University of Edinburgh.

Moldt, Dirk (Ed.). (2005). Der mOaning star, 1985-1989: Eine Ostberliner Untergrundpublikation. Berlin: Robert-Havemann-Gesellschaft.

Moore, Francesca (2010). Tales from the archive: Methodological and ethical issues in historical geographical research Area, 42(3): 262-270.

Nuga, Mari, Leetmaa, Kadri and Tammaru, Tiit (2016). Exploring homes in Estonian socialist-era summerhouse settlements. International Journal of Urban and Regional Research 40(4): 866-883.

Owens, Lynn (2009). Cracking under pressure: Narrating the decline of the Amsterdam squatters’ movement. Amsterdam: Amsterdam University Press.

Palmowski, Jan (2009). Inventing a socialist nation: Heimat and the politics of everyday life in the GDR, 1945-1990. Cambridge: Cambridge University Press.

Pfaff, Steven (2006). Exit-voice dynamics and the collapse of East Germany: The crisis of Leninism and the revolution of 1989. Durham, NC: Duke University Press. 
Pieterse, Edgar and Simone, AbdouMaliq (2017). New urban worlds: Inhabiting dissonant times. Cambridge: Polity.

Port, Andrew (2007). Conflict and stability in the German Democratic Republic. Cambridge: Cambridge University Press.

Roy, A. (2015). Whose afraid of postcolonial theory? International Journal of Urban and Regional Research 40(1): 200-209.

Rubin, Eli (2016). Amnesiopolis: Modernity, Space and memory in East Germany. Oxford: Oxford University Press.

Safransky, Sara (2018). Land justice as historical diagnostic: Thinking with Detroit. Annals of the American Association of Geographers 108(2): 499-512.

Squatting Europe Kollective or SqEK (Eds.). (2014). The squatters' movement in Europe: Commons and autonomy as alternatives to capitalism. London: Pluto Press.

Stoler, Ann Laura (2009). Along the archival grain: Epistemic anxieties and colonial common sense. Princeton: Princeton University Press.

Szelénya, Iván (1983). Urban inequalities under state socialism. Oxford: Oxford University Press. 
Tuvikene, Tauri (2016). Strategies for comparative urbanism: Post-socialism as a deterritorialized concept. International Journal of Urban and Regional Research 40(1): 132146.

Tuvikene, Tauri, Alves, Susanna and Hilbrandt, Hanna (2017). Strategies for relating diverse cities: A multi-sited individualising comparison of informality in Bafatá, Berlin and Tallinn. Current Sociology 65(2): 276-288.

Wensierski, Peter and Büscher, Wolfgang (1983). 'Wenn du unter bist, tauscht du ab: DDRJugendszene (1): Punker und Aussteiger. Spiegel, 40, October 3, 1983.

Zarecor, Kimberly (2018). What was so socialist about the socialist city? Second World Urbanity in Europe. Journal of Urban History 441(1): 95-117.

Zatlin, Jonathan (2007). The currency of socialism: Money and political culture in East Germany. Cambridge: Cambridge University Press.

Zegarac, Z. (1999). Illegal construction in Belgrade and the prospects for urban development planning. Cities, 16(5): 365-370. 